\title{
OTEC Thermal Resource Report for Sri Lanka
}

May 1979

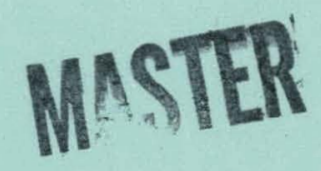

Prepared for

U.S. Department of Energy

Assistant Secretary for Energy Technology

Division of Central Solar Technology

Under Contract No. ET-78-C-01-2898 


\section{DISCLAIMER}

This report was prepared as an account of work sponsored by an agency of the United States Government. Neither the United States Government nor any agency Thereof, nor any of their employees, makes any warranty, express or implied, or assumes any legal liability or responsibility for the accuracy, completeness, or usefulness of any information, apparatus, product, or process disclosed, or represents that its use would not infringe privately owned rights. Reference herein to any specific commercial product, process, or service by trade name, trademark, manufacturer, or otherwise does not necessarily constitute or imply its endorsement, recommendation, or favoring by the United States Government or any agency thereof. The views and opinions of authors expressed herein do not necessarily state or reflect those of the United States Government or any agency thereof. 


\section{DISCLAIMER}

Portions of this document may be illegible in electronic image products. Images are produced from the best available original document. 
Available from:

National Technical Information Service (NTIS)

U.S. Department of Commerce

5285 Port Royal Road

Springfield, Virginia 22161

Price: Printed copy: $\$ 4.50$

Microfiche: $\$ 3.00$ 
HCP/T2898-01/2

Dist Cat UC-

\section{OTEC Thermal Resource Report for Sri Lanka}

May 1979

Prepared for

U.S. Department of Energy

Assistant Secretary for Energy Technology

Division of Central Solar Technology

Washington, D.C. 20585

Prepared by

William Alan Wolff

Ocean Data Systems, Inc.

Monterey, California 93940

Under Contract No. ET-78-C-01-2898

This report was prepared as an account of work

spnnsored by the United States Government. Neither the

United States not the United States Department of

Energy, nor any of their employees, nor any of their

imatractors, subeontractors, or their employees, makes

any warranty, express or implied, or assumes any legal

liability or responsibility for the accumey, comple teness

or usefutness of any information, apparatus, product or

or usefutness of any information, apparatu, produld not
process disclosed, or represents that its use would

iiff iñte: privotely' ounnod rightte. 


\section{NOTICE}

This report was prepared as an account of work sponsored by the United States Government. Neither the United States nor the United States Department of Energy, nor any of their employees, makes any warranty, express or implied, or assumes any legal liability or responsibility for the accuracy, completeness, or usefulness of any information, apparatus, product, or process disclosed, or represenis that its use would not infringe privately owned rights. Reference herein to any specific commercial product, process, or service by trade name, mark, manufacturer, or otherwise, does not necessarily constitute or imply its endorsement, recommendation, or favoring by the United States Government or any agency thereof. The views and opinions of au thors expressed herein do not necessarily state or reflect those of the United States Government or any agency thereof. S 
Section

INTRODUCTION .........................

I.

II.

III.

IV.

$\mathrm{V}$.

VI.

VII.

REFERENCES
EXECUTIVE SUMMARY ................... I

BATHYMETRY......................... II-I

THERMAL RESOURCE.............................. III

MIXED IAYYER DEPTH................... IV-I

WEATHER CONDITIONS................... V-1

SEA AND SWELL CHARACTERISTICS............ VI-I

CURRENTS.................................. VII

$\mathrm{R}-1$ 
INTRODUCTION

One of the basic environmental considerations in site selection for an Ocean Thermal Energy Conversion (OTEC) power plant is the availability of an adequate temperature difference resource. OTEC plants are designed to convert the potential energy in the temperature difference between the warm ocean surface water and the cold water existing at deeper depths into electricity. The turbines which produce the electricity must run on temperature differentials which are extremely small by the standards of conventional energy plants. Therefore, a definition of the most probable temperature structure for a site is most important.

In order to define temperature structures for OTEC areas of interest, Ocean Data Systems, Inc. (ODSI) has developed computer data files of all unclassified soundings available. The primary sources for the data were NOAA's National Oceanographic Data Center, and the U.S. Navy's Fleet Numerical Weather Céntral. The files were updated in September 1978. Included in the data base were mechanical bathythermographs (MBT), expendable bathythermographs (XBT), salinity temperature depth systems (STD), and Nansen casts.

Under U.S. Department of Energy, Division of Solar Energy Contract No. EY-78-C-2989, ODSI has analyzed the monthly temperature structure for ten different geographical areas. The ten sites selected for study by the Department of Energy are: 


\section{Latitude Longitude}

Bottom Mounted

or

Shore Plants: Dampier Land $13-18^{\circ} \mathrm{S} \quad 118-121^{\circ} \mathrm{E}$

\begin{tabular}{|c|c|c|c|}
\hline & Manila & $14-16^{\circ} \mathrm{N}$ & $118-120^{\circ} \mathrm{E}$ \\
\hline & Guam & $12-15^{\circ} \mathrm{N}$ & $142-146^{\circ} \mathrm{E}$ \\
\hline \multirow{5}{*}{ 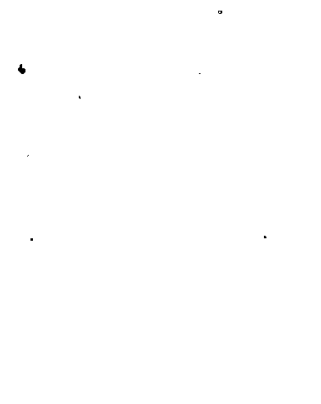 } & Ivory Coast & $3-6^{\circ} \mathrm{N}$ & $3-8^{\circ} \mathrm{W}$ \\
\hline & Jakarta & $6-9^{\circ} \mathrm{S}$ & $104-109^{\circ} \mathrm{E}$ \\
\hline & Mexico & $20-23^{\circ} \mathrm{N}$ & $105-110^{\circ} \mathrm{W}$ \\
\hline & Sri Lanka & $5-10^{\circ} \mathrm{N}$ & $78-83^{\circ} \mathrm{E}$ \\
\hline & Mombasa & $2_{0} \mathrm{~T}-3^{\circ} \mathrm{N}$ & $40-45^{n} \mathrm{E}$ \\
\hline \multirow[t]{2}{*}{ Ship Plants: } & No. 1 & $5-10^{\circ} \mathrm{N}$ & $90-95^{\circ} \mathrm{W}$ \\
\hline & No. 2 & $13-15^{\circ} \mathrm{N}$ & $75-80^{\circ} \mathrm{W}$ \\
\hline
\end{tabular}

The location of these sites is shown on the following map; a separate report was produced for each site.

For each area, the most probable temperature structures were determined. When the most probable temperature soundings were plotted, some month to month variability was present which was caused by the non-uniform data sample rather than by real changes in the ocean. These short-period time variations were removed by a filtering process described by Wolff, et al (1977), [4]. Availability of cold and warm water was examined at each site. In addition to warm and cold water availability, there are other requirements for the continuous operation of an OTEC plant. An adequate temperature differential $(\Delta T)$ is the primary need. A $\Delta T$ greater than $16.7^{\circ} \mathrm{C}\left(30^{\circ} \mathrm{F}\right)$ for the coldest month of the year would enable year round operation. The annual mean $\Delta T$ for 


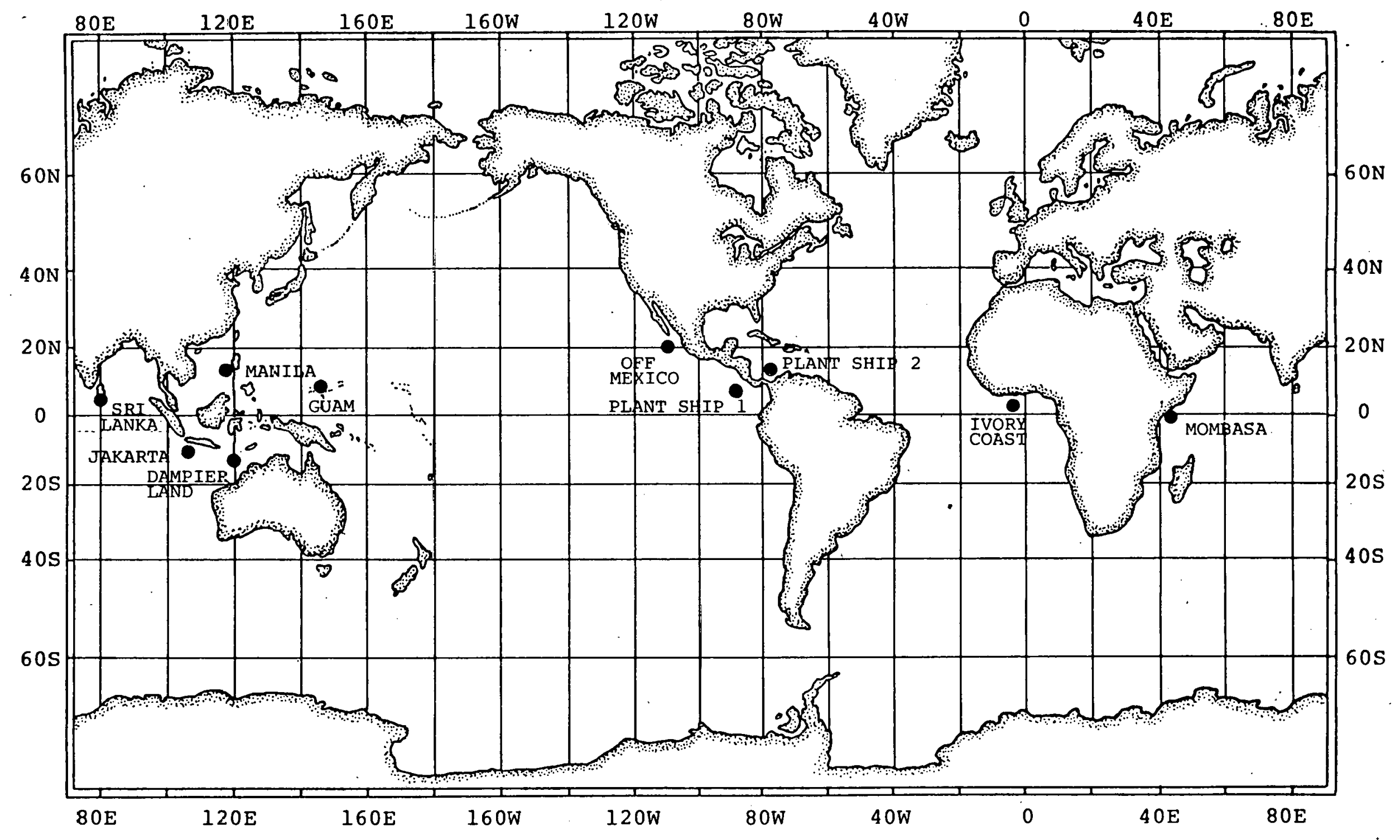

LOCATION OF THE TEN SELECTED SITES 
a site should equal or exceed $20^{\circ} \mathrm{C}\left(36^{\circ} \mathrm{F}\right)$. Besides the thermal resource; there are other operational requirements. Bottom depth should be less than 1500 meters for mooring. Minimum distances offshore to 1000-meter depth is another important consideration for shore plants. Currents should be sufficient to guarantee good cold/warm water sources and to provide for dispersion of modified water. Desirable sites also have light winds, minimum sea and swell, and the lack of severe storms. These parameters have been examined for each site. The following tables sumnarize some of the key site parameters for each location. . 
SUMMARY OF SITE PARAMETERS

\begin{tabular}{|c|c|c|c|c|c|c|}
\hline Site & $\begin{array}{l}\text { Monthly Mean } \\
\text { Temperature }\left({ }^{\circ} \mathrm{C}\right) \\
\text { Surface Range }\end{array}$ & $\begin{array}{l}\text { Monthly Mean } \\
\text { Temperature }\left({ }^{\circ} \mathrm{C}\right) \\
\text { lo00M }\end{array}$ & $\begin{array}{c}\text { Annual } \\
\text { Mean } \\
\Delta \mathrm{T}\left({ }^{\circ} \mathrm{C}\right) 500 \mathrm{M}\end{array}$ & $\begin{array}{c}\text { Annual } \\
\text { Mean } \\
\Delta \mathrm{T}\left({ }^{\circ} \mathrm{C}\right) 1000 \mathrm{M}\end{array}$ & $\begin{array}{c}\text { Coldest Monthly } \\
\text { Mean } \Delta \mathrm{T}\left({ }^{\circ} \mathrm{C}\right) \\
500 \mathrm{M}\end{array}$ & $\begin{array}{c}\text { Coldest Monthly } \\
\text { Mean } \Delta \mathrm{T}\left({ }^{\circ} \mathrm{C}\right) \\
1000 \mathrm{M}\end{array}$ \\
\hline Sri Lanka & $27.5-28.6$ & $6.5-6.7$ & 18.0 & 21.3 & 17.5 & 20.8 \\
\hline Mombasà $\mathrm{N}$ & $25.4-28.7$ & $7.2-7.5$ & 17.0 & 19.5 & .15 .6 & 18.2 \\
\hline Mombasa $\mathrm{S}$ & $25.5-28.4$ & $6.3-7.0$. & 18.0 & 20.2 & 15.9 & 18.5 \\
\hline Jakarta & $27.2-29.0$ & $5.1-5.6$ & 19.1 & 22.8 & 17.9 & 21.9 \\
\hline Manila & $27.1-29.5$ & $4.4-4.6$ & 20.0 & 24.0 & 18.6 & 22.6 \\
\hline Guam & $27.7-29.2$ & $4.3-4.4$ & 21.1 & 24.1 & 20.4 & 23.4 \\
\hline Off Mexico & $22.5-28.0$ & $4.4-4.5$ & 17.6 & $20.9^{\circ}$ & 14.9 & 18.0 \\
\hline $\begin{array}{c}\text { Plant Ship } \\
\text { Pacific }\end{array}$ & $27.1-28.5$ & $4.6-4.8$ & 19.4 & 22.8 & 18.1 & 21.7 \\
\hline Ivory Coast & $24.3-28.1$ & 4.5 & 19.2 & 22.1 & 16.8 & 19.7 \\
\hline
\end{tabular}


SUMMARY OF SITE PARAMETERS






\section{EXECUTIVE SUMMARY}

The water surrounding the island of Sri Lanka has a temperature difference resource which is more than adequate for potential OTEC use. The temperature resource was examined between $5^{\circ}-10^{\circ}$ North latitude and $78^{\circ}-83^{\circ}$ East longitude. This area includes the surrounding waters on all sides of Sri Lanka. There is a large area north and northwest of the island where there is insufficient depth to provide the needed cold water supply. The annual average $\Delta \mathrm{T}$ at 1000 meters is $21.3^{\circ} \mathrm{C}$. An annual average $\Delta \mathrm{T}$ greater than $20^{\circ} \mathrm{C}$ is available at 800 meters. The temperature is very consistent at depths with little difference between the coldest monthly mean temperature and the warmest.

The area has an upper mixed layer the entire year, (deepest in January-February and shallowest in the fall). Winds and storms are not a major problem for this site, although there are occasional tropical storms or hurricanes. Low to moderate sea and swell conditions generally dominate throughout the year. The surface currents are generally moderate throughout the year, changing direction with the shifting monsoons. 
Ï̈. BATHYMETRY

Figure II-1 shows the location of a potential site off Sri Lanka. Although only a site on the east coast of the island is indicated, sites on the western or southern coasts of the island are also possible. The area studied for the. Sri Lanka site was from $5^{\circ}-10^{\circ}$ North latitude and between ' $78^{\circ}-83^{\circ}$ East longitude. A rough bathymetry of the area is shown in Figure II-2. The source for this bathymetry is the Defense Mapping Agency Hydrographic Center publication N.O. 721, Indian Ocean, Northern Part (1974), [11].

Northwest of the island is an extensive shallow area in which the bottom is less than 100 meters deep. This is also true for some of the area due north of the island. Depths of 1000 and 1500 meters are available west, south, east, and northeast of the island. West of Colombo, the largest city and seaport, the 1000 meter depth is within $20 \mathrm{~km}$ of shore. The distance from shore to specified depths is shown in Table II-1.

TABLE II-1: DISTANCE FROM SHORE TO SPECIFIED DEPTHS IN KILOMETERS AND (NAUTICAL MILES)

\begin{tabular}{|lcccc|}
\hline $\begin{array}{c}\text { Closest } \\
\text { Distance to: }\end{array}$ & $\mathrm{N}$ & $\mathrm{E}$ & $\mathrm{D}$ & $W$ \\
\hline 100 Meters & $22.0(12)$ & $14.8(8)$ & $14.8(8)$ & $14.8(8)$ \\
\hline 500 Meters & $38.9(21)$ & $31.5(17)$ & $24.0(13) 18.5(10)$ \\
\hline 1000 Meters & $55.0(30)$ & $38.9(21)$ & $38.9(21) 22.2(12)$ \\
\hline
\end{tabular}




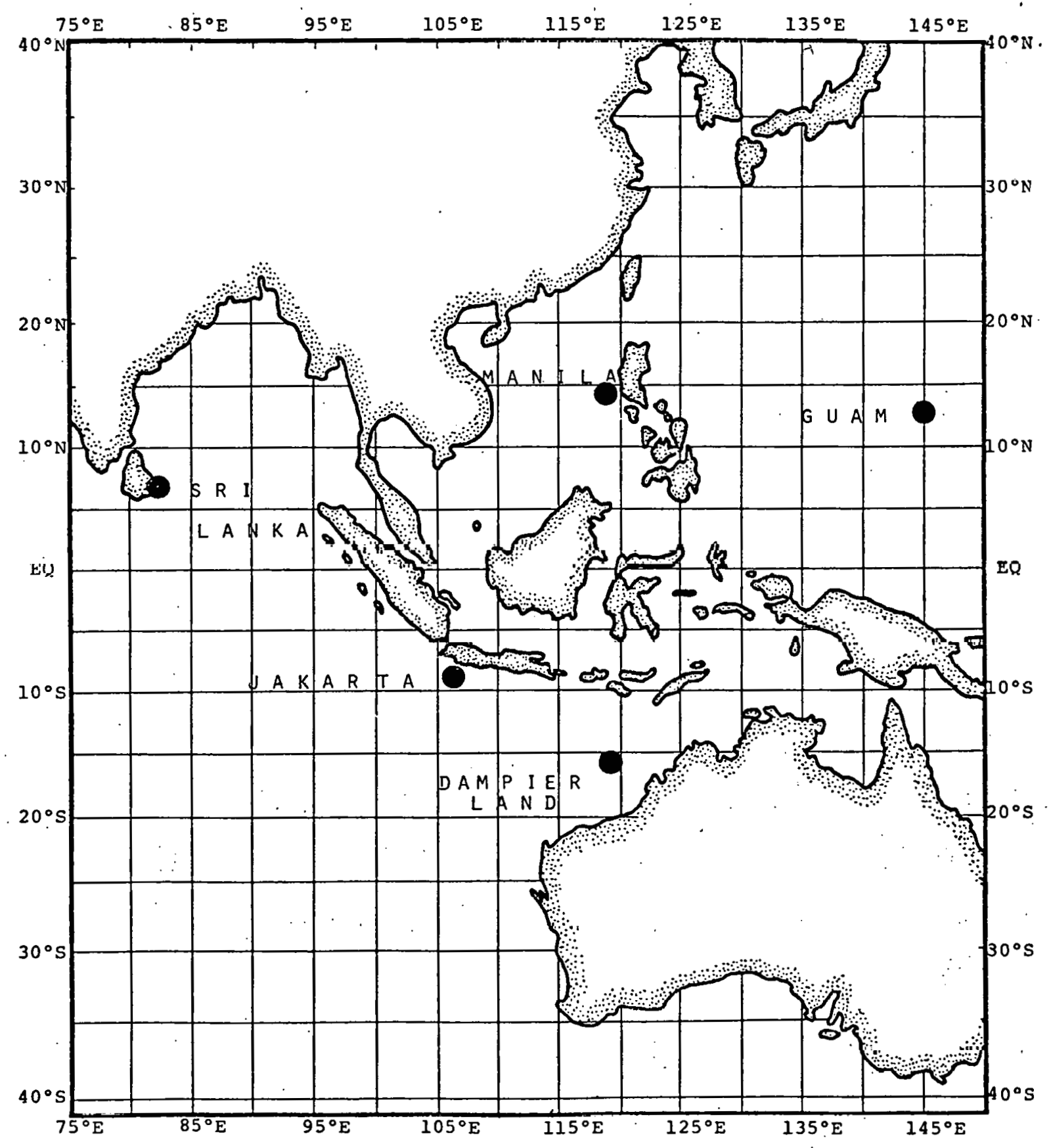

FIGURE II-1: LOCATOR CHART

II -2 


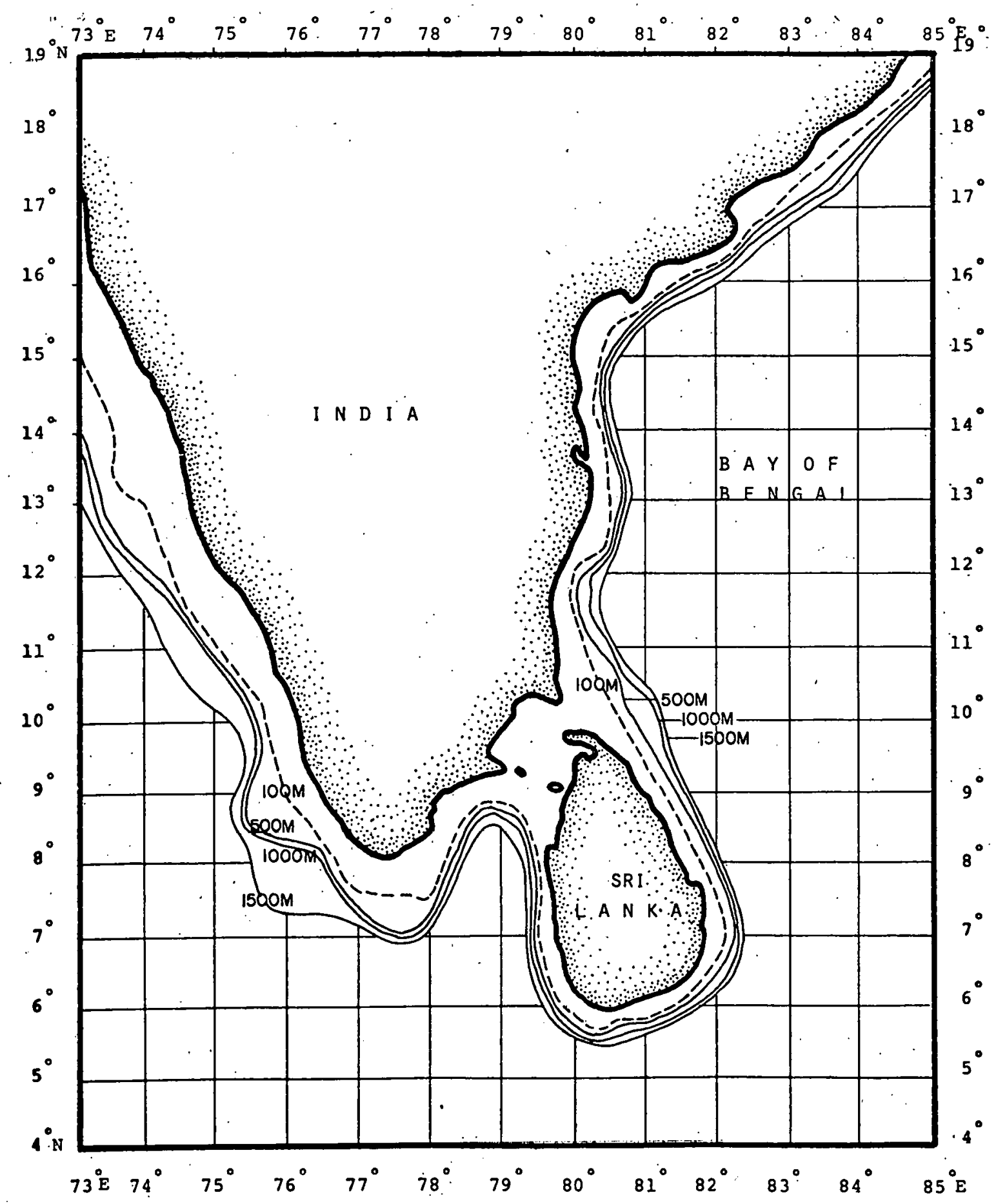

FIGURE II-2: ROUGH BATHYMETRY TO 1500 METERS OFF SRI IANKA 
III. THERMAL RESOURCE

There was temperature data for every month of the year and at each 50-meter level from the surface to the 1500meter depth. The main.sources for this data were NOAA's National Oceanographic Data Center, and the U.S. NavY Fleet Numerical weather Central, although soundings from university or other sources were added when available. The data at depth and for some months of the year is sparse.

When the available data was plotted, some month-tomonth variability was present which was caused by the sparse and non-uniform data sample rather than by real changes in the ocean. These short-period time variations were removed by a filtering process, described by Wolff, et al (1977), [4 $\underline{4}]$.

The thermal resource is a good one, although not quite as good as several of the other ten sites being studied under this contract. While there are observations of $30^{\circ} \mathrm{C}$ or greater in the upper layer', the monthly mean surface temperature for nine months was between $27^{\circ} \mathrm{C}$ and $28^{\circ} \mathrm{C}$. The winter surface waters are influenced by the slightly cooler Bay of Bengal waters. The temperatures at depths of 1000 meters in the Indian Ocean, including the waters surrounding Sri Lanka, are several degrees Centigrade warmer than sites in the Atlantic and Pacific. The average mean temperature at 1000 meters is $6.6^{\circ} \mathrm{C}$ for the sri Lanka site region. 
Table, III-l provides the monthly most probable temperature $\left({ }^{\circ} \mathrm{C}\right)$ profile for sri Lanka. The annual mean temperatures for each depth were computed by averaging the monthly most probable temperature figures. Table III-2 provides $\Delta \mathrm{T}$; the surface temperature minus the temperature at depth differential $\left({ }^{\circ} \mathrm{C}\right)$ by months. The annual mean $\Delta \mathrm{T}$, was computed by taking the differential of the annual mean surface temperature and the annual mean temperature at depth from Table III-1. Figure III-3 provides a plot of monthly $\Delta \mathrm{T}$ contours for the Sri Lanka site; 
MONTHLY MOST PROBABLE TEMPERATURE ( $\left.{ }^{\circ} \mathrm{C}\right)$ PROFILE SRI LANKA $5-10^{\circ} \mathrm{N} / 78-83^{\circ} \mathrm{E}$

\begin{tabular}{|c|c|c|c|c|c|c|c|c|c|c|c|c|c|}
\hline \multirow[t]{2}{*}{ Depth } & \multicolumn{12}{|c|}{ Month } & \multirow[t]{2}{*}{$\begin{array}{l}\text { Annual } \\
\text { Mean. }\end{array}$} \\
\hline & 1 & 2 & 3 & 4 & 5 & 6 & 7 & 8 & 9 & 10 & 11 & 12 & \\
\hline 0 & 27.5 & 27.5 & 8.3 & 28.6 & 28.6 & 28.0 & 27.5 & 27.6 & 27.7 & 27.8 & 27.9 & 27.8 & 27.9 \\
\hline 50 & 27.2 & 27.3 & 27.5 & 27.5 & 27.0 & 6.5 & 25.3 & 25.5 & 25.5 & 27.0 & 27.3 & 27.5 & 6.8 \\
\hline 100 & 22.8 & 23.9 & 22.9 & 22.3 & 21.6 & 20.8 & 20.2 & 19.7 & 20.3 & 1.6 & 6 & 2.8 & 1.7 \\
\hline 150 & 17.5 & $17: 7$ & 17.1 & 16.8 & 16.9 & 16.0 & 15.3 & 15.6 & 16.1 & 16.7 & 16.7 & 17.2 & 6.6 \\
\hline 200 & 14.4 & 14.4 & 14.1 & 14.0 & 13.8 & 13.6 & 13.3 & 13.6 & 13.8 & 13.7 & 13.7 & 13.9 & 13.9 \\
\hline 250 & 13.0 & $12: 9$ & 12.7 & 12.6 & 12.5 & 12.5 & 12.2 & 12.5 & 12.7 & 12.5 & 12.6 & 12.6 & 12.6 \\
\hline 300 & 12.0 & 12.0 & 11.8 & i1. 9 & 11.8 & 11.8 & 11.7 & 11.7 & 11.9 & 1.1 .7 & 11.8 & 11.7 & 1.8 \\
\hline 350 & 11.3 & 11.3 & 11.2 & 11.3 & 11.3 & 11.3 & 11.2 & 11.2 & 11.3 & 11.2 & 11.3 & 1.3 & 1.3 \\
\hline 400 & 10.9 & 10.8 & 10.7 & 10.8 & 10.8 & 10.8 & 10.7 & 10.8 & 10.9 & 10.8 & 10.8 & 10.7 & 10.8 \\
\hline 450 & 10.4 & 10.4 & 10.3 & 10.4 & 10.4 & 10.4 & 10.4 & 10.4 & 10.5 & 10.3 & 10.4 & 10.3 & 10.4 \\
\hline 500 & 10.0 & 10.0 & 9.9 & 10.0 & 10.1 & 10.0 & 9.9 & 9.8 & 9.9 & 9.8 & 9.8 & 9.9 & 9.9 \\
\hline 550. & 9.6 & 9.6 & 9.6 & 9.6 & 9.6 & 9.5 & 9.5 & 9.4 & 9.6 & 9.5 & 9.5 & 9.5 & 9.6 \\
\hline 600 & 9.3 & 9.2 & 9.2 & 9.2 & 9.2 & 9.2 & 9.2 & 9.2 & 9.3 & 9.2 & 9.1 & 9.2 & 9.2 \\
\hline 650 & 8.9 & 8.9 & 8.9 & 960 & 8.9 & 8.8 & $8.8^{\circ}$ & 8.8 & 8.9 & 8.8 & 8.8 & 8.8 & 8.9 \\
\hline 700 & 8.5 & 8.5 & 8.5 & 8.6 & 8.6 & 8.7 & 8.6 & 8.6 & 8.5 & 8.5 & 8.5 & 8.5 & 8.5 \\
\hline 750 & 8.1 & 8.2 & 8.2 & 8.3 & 8.3 & 8.3 & 8.2 & 8.2 & 8.2 & 8.2 & 8.1 & 8.1 & 8.2 \\
\hline 800 & .8 & 7.9 & 7.8 & 7.9 & 7.9 & 7.9 & 7.8 & 7.8 & 7.8 & 7.8 & 7.8 & 7.9 & 7.8 \\
\hline 850 & .5 & 7.5 & 7.4 & 7.5 & 7.6 & 7.7 & 7.6 & 7.5 & 7.5 & & 7.5 & 7.5 & 7.5 \\
\hline 900 & 7.2 & 7.2 & 7.1 & 7.1 & 7.2 & 7.3 & 7.3 & 7.2 & 2 & 2 & .2 & .7 .2 & 7.2 \\
\hline 950 & 6.9 & 6.8 & 6.8 & 6.8 & 6.9 & 7.0 & 7.0 & 6.9 & 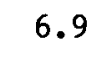 & $y$ & .9 & 6.9 & 6.9 \\
\hline 1000 & 6.6 & 6.5 & 6.5 & 6.5 & 6.6 & 6.7 & 6.7 & 6.7 & 6.6 & 6.6 & 6.6 & 6.6 & 6.6 \\
\hline 1050 & 6.3 & 6.2 & 6.2 & 6.2 & 6.3 & 6.4 & 6.4 & 6.4 & 6.4 & 6.4 & 6.4 & 6.4 & 6.3 \\
\hline 1100 & 6.0 & 6.0 & 6.0 & 6.0 & 6.0 & 6.1 & 6.1 & 6.2 & 6.1 & 6.1 & 6.1 & 6.1 & 6.1 \\
\hline 1150 & 5.8 & 5.7 & 5.7 & 5.7 & 5.7 & 5.8 & 5.9 & 5.9 & 5.9 & 5.9 & 5.9 & 5.8 & 5.8 \\
\hline 1200 & 5.5 & $5: 5$ & 5.5 & 5.5 & 5.5 & 5.6 & 5.6 & 5.6 & 5.6 & 5.7 & 5.6 & 5.6 & $5: 6$ \\
\hline 1250 & 5.3 & 5.3 & 5.4 & 5.3 & 5.3 & 5.3 & 5.4 & 5.4 & 5.4 & 5.4 & 5.4 & 5.3 & 5.4 \\
\hline 1300 & 5.1 & 5.1 & 5.2 & 5.1 & 5.1 & 5.1 & 5.2 & 5.2 & 5.2 & 5.2 & 5.2 & 5.1 & 5.2 \\
\hline 1350 & 4.9 & 4.9 & 5.0 & 4.9 & 4.9 & 4.9 & 5.0 & 5.0 & 5.0 & 5.0 & 4.9 & 4.8 & 4.9 \\
\hline 1400 & 4.7 & 4.8 & 4.9 & 4.8 & 4.7 & 4.7 & 4.7 & 4.8 & 4.8 & 4.7 & 4.7 & 4.6 & 4.8 \\
\hline 1450 & 4.5 & 4.6 & 4.6 & 4.7 & 4.6 & 4.5 & 4.5 & 4.5 & 4.5 & 4.5 & 4.5 & 4.4 & 4.5 \\
\hline 1500 & 4.2 & 4.3 & $4: 4$ & 4.5 & 4.4 & 4.3 & 4.3 & 4.3 & 4.3 & 4.3 & 4.2 & 4.2 & $4: 3$ \\
\hline
\end{tabular}


TABLE III-2

SURFACE TEMPERATURE - TEMPERATURE AT DEPTH

DIFFERENTIAL $\left({ }^{\circ} \mathrm{C}\right)$ BY MONTHS SRI LANKA $5-10^{\circ} \mathrm{N} / 78-83^{\circ} \mathrm{E}$

\begin{tabular}{|c|c|c|c|c|c|c|c|c|c|c|c|c|c|}
\hline Depth & 1 & 2 & 3 & 4 & 5 & $\begin{array}{c}\text { Month } \\
6\end{array}$ & 7 & 8 & 9 & 10 & 11 & 12 & $\begin{array}{c}\text { Annual } 1 \\
\text { Mean }\end{array}$ \\
\hline 50 & 0.3 & 0.2 & 0.8 & 1.1 & 1.6 & 1.5 & $2.2^{\circ}$ & 2.1 & 2.2 & 0.8 & 0.6 & 0.3 & 1.1 \\
\hline 100 & 4.7 & $3.6^{\circ}$ & 5.4 & 6.3 & 7.0 & 7.2 & 7.3 & 7.9 & 7.4 & 6.2 & 6.3. & 5.0 & 6.2 \\
\hline 150 & 10.0 & 9.8 & 11.2 & 11.8 & 11.7 & 12.0 & 12.2 & 12.0 & $11: 6$ & 11.1 & 11.2 & 10.6 & 11.3 \\
\hline 200 & 13.1 & 13.1 & 14.2 & 14.6 & 14.8 & 14.4 & 14.2 & 14.0 & 13.9 & 14.1 & 14.2 & 13.9 & 14.0 \\
\hline 250 & 14.5 & 14.6 & 15.6 & 16.0 & 16.1 & 15.5 & 15.3 & 15.1 & 15.0 & 15.3 & 15.3 & 15.2 & 15.3 \\
\hline 300 & 15.5 & 15.5 & 16.5 & 16.7 & 16.8 & 16.2 & 15.8 & 15.9 & 15.8 & 16.1 & 16.1 & 16.1 & 16.1 \\
\hline 350 & 16.2 & 16.2 & 17.1 & 17.3 & 17.3 & 16.7 & 16.3 & 16.4 & 16.4 & 16.6 & 16.6 & 16.5 & 16.6 \\
\hline 400 & 16.6 & 16.7 & 17.6 & 17.8 & 17.8 & 17.2 & 16.8 & 16.8 & 16.8 & 17.0 & 17.1 & 17.1 & 17.1 \\
\hline 450 & 17.1 & 17.1 & 18.0 & 18.2 & 18.2 & 17.6 & 17.1 & 17.2 & 17.2 & 17.3 & 17.5 & 17.5 & 17.5 \\
\hline 500 & 17.5 & 17.5 & 18.4 & 18.6 & .18 .5 & 18.0 & 17.6 & 17.8 & 17.8 & 18.0 & 18.1 & 17.9 & 18.0 \\
\hline 550 & 17.9 & 17.9 & 18.7 & 19.0 & 19.0 & 18.5 & 18.0 & 18.2 & 18.1 & 18.3 & 18.4 & 18.3 & 18.4 \\
\hline 600 & 18.2 & 18 & 19.1 & 19.4 & 1 & 1 & 18.3 & 18.4 & 18.4 & 10.0 & 18.8 & 18.6 & 18.7 \\
\hline 650 & 18.6 & 18.6 & 19.4 & 19.6 & 19.7 & 19.2 & 18.7 & 18.8 & 18.8 & 19.0 & 19.1 & 19.0 & 19.0 \\
\hline 700 & 19.0 & 19.0 & 19.8 & 20.0 & 20.0 & 19.3 & 18.9 & 19.0 & 19.2 & 19.3 & 19.4 & 19.3 & 19.4 \\
\hline 750 & 19.4 & 19.3 & 20.1 & 20.3 & 20.3 & 19.7 & 19.3 & 19.4 & 19.5 & 19.6 & 19.8 & 19.7 & 19.7 \\
\hline 800 & 19.7 & 19.6 & 20.5 & 20.7 & 20.7 & 20.1 & 19.7 & 19.8 & 19.9 & 20.0 & 20.1 & 19.9 & 20.1 \\
\hline 850 & 20.0 & 20.0 & 20.9 & 21.1 & 21.0 & 20.3 & 19.9 & 20.1 & 20.2 & 20.3 & 20.4 & 20.3 & 20.4 \\
\hline 900 & 20.3 & 20.3 & 21.2 & 21.5 & 21.4 & 20.7 & 20.2 & 20.4 & 20.5 & 20.6 & 20.7 & 20.6 & 20.7 \\
\hline 950 & 20.6 & 20.7 & 21.5 & 21.8 & 21.7 & 21.0 & 20.5 & 20.7 & 20.8 & 20.9 & 21.0 & 20.9 & 21.0 \\
\hline 1000 & 20.9 & 21.0 & 21.8 & 22.1 & 22.0 & 21.3 & 20.8 & 20.9 & 21.1 & 21.2 & 21.3 & 21.2 & 21.3 \\
\hline 1050 & 21.2 & 21.3 & 22.1 & 22.4 & 22.3 & 21.6 & 21.1 & 21.2 & 21.3 & 21.4 & 21.5 & 21.4 & 21.6 \\
\hline 1100 & 21.5 & 21.5 & 22.3 & 22.6 & 22.6 & 21.9 & 21.4 & 21.4 & 21.6 & 21.7 & 21.8 & 21.7 & 21.8 \\
\hline 1150 & 21.7 & 21.8 & 22.6 & 22.9 & 22.9 & 22.2 & 21.6 & 21.7 & 21.8 & 21.9 & 22.0 & 22.0 & 22.1 \\
\hline 1200 & 22.0 & 22.0 & 22.8 & 23.1 & 23.1 & 22.4 & 21.9 & 22.0 & 22.1 & 22.1 & 22.3 & 22.2 & 22.3 \\
\hline 1250 & 22.2 & 22.2 & 22.9 & 23.3 & 23.3 & 22.7 & 22.1 & 22.2 & 22.3 & 22.4 & 22.5 & 22.5 & 22.6 \\
\hline 1300 & 22.4 & 22.4 & 23.1 & 23,5 & 23.5 & 22.9 & 22.3 & 22.4 & 22.5 & 22.6 & 22.7 & 22.7 & 22.8 \\
\hline 1350 & 22.6 & 22.6 & 23.3 & 23.7 & 23.7 & 23.1 & 22.5 & 22.6 & 22.7 & 22.8 & 23.0 & 23.0 & 23.0 \\
\hline 1400 & 22.8 & 22.7 & 23.4 & 23.8 & 23.9 & 23.3 & 22.8 & 22.8 & 22.9 & 23.1 & 23.2 & 23.2 & 23.2 \\
\hline 1450 & 23.0 & 22.9 & 23.7 & 23.9 & 24.0 & 23.5 & 23.0 & 23.1 & 23.2 & 23.3 & 23.4 & 23.4 & 23.4 \\
\hline 1500 & 23.3 & 23.2 & 23.9 & 24.1 & 24.2 & 23.7 & 23.2 & 23.3 & 23.4 & 23.5 & 23.7 & 23.6 & 23.6 \\
\hline
\end{tabular}




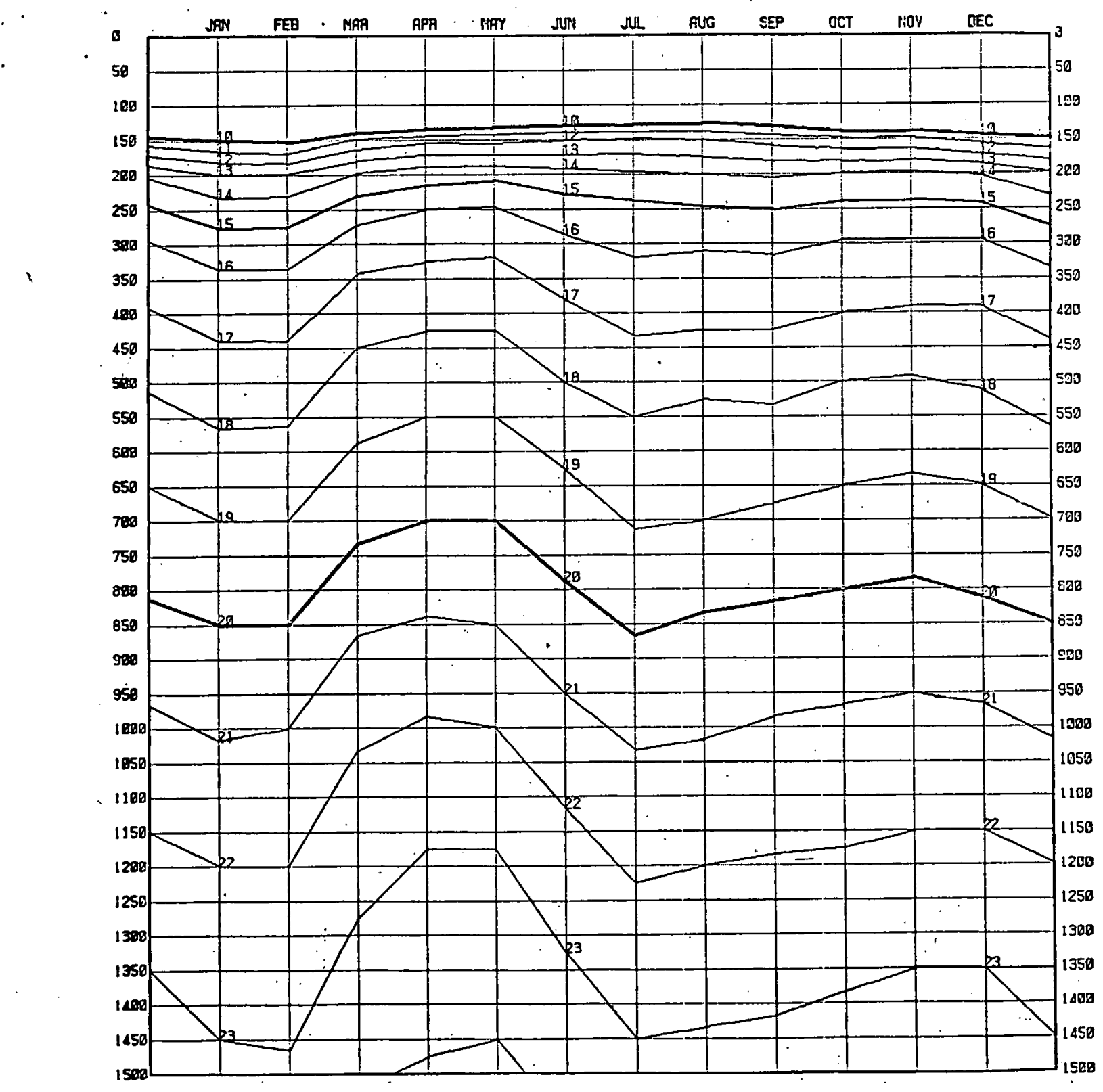

FIGURE III-I: CHART SHOWING MONTHLY $\triangle T$ TONTOURS $\left({ }^{\circ} \mathrm{C}\right)$ AT A DEPTH RESOLUTION OF 50 METERS OFF SRI LANKA (5-10N/78-83E) 
IV. MIXED LAYER DEPTH

An upper mixed layer is found in the coastal waters of Sri Lanka throughout the year. Between November and February the Mixed Layer Depth (MLD) is the deepest (generally at least 50 meters in depth). From May to June, the MLD is shallower (generally ranging between 30-50 meters in depth). The depth of the mixed layer varies slightly depending on which coast is chosen for the site. Depths of the MLD (in meters) off the respective coasts are as follows:

JAN-FEB MAR-APR MAY-JUN JUL-AUG SEP-OCT NOV-DEC

$\begin{array}{lllllll}\text { North Coast } & 50 & 35 & 30 & 50 & 35 & 50 \\ \text { East Coast } & 50 & 50 & 30 & 30 & 50 & 50 \\ \text { West Coast } & 70 & 50 & 30 & 30 & 50 & 50 \\ \text { South Coast } & 80 & 50 & 40, & 40 & 55 & 50\end{array}$

This mixed layer should be adequate for OTEC purposes, since it is deep enough to assure an intake of uniformly warm water at or very close to the surface temperature. Also, the mixed layer depth off Sri Lanka is not so deep that discharged exhaust water will cause recirculation problems. The Thermal Structure of the Indian Ocean by Colburn (1974), [6] was consulted for mixed layer depth values together with our own temperature data file. The mixed layer depth was defined for OTEC purposes to be the depth at which the temperature is first colder than the surface value by $1^{\circ}$ Centigrade. 
V. WEATHER CONDITIONS

Table V-1, taken from the U.S. Naval Weather Service, (1973), [36] shows basic climatic information for the city of Colombo, sri Lanka. It is clear that there are two rainy seasons and a distinct monsoonal wind regime. The area exhibits steady flow from the west or southwest from May through september and a steady wind flow from the northeast from November through February. In the fall and spring transition periods winds are more variable in both speed and direction. This is verified by wind flow statistics for water areas around Sri Lanka as shown in Table V-2 (fxom and U.S. Dept. of Agriculture, (1938), [31]).

Sri Lanka lies on the southern edge of the tropical storm/cyclone belt in the Indian Ocean. Figure V-l shows the preferred tropical storm tracks for the region while. Figure $V-2$ shows the average number of tropical cyclones per 5 degree square per year. Both figures are from Crutcher and Quayle (1974), [7]: A recent climatic study by the U.S. Naval Weather Service (1972), [36] confirms these statistics; their results are summarized in Table $\mathrm{V}-3$.

Hurricanes will cause winds which may sustain speeds of 30 to 50 meters per second. Mountainous waves can be produced. Gentry (1970), [18] states that occasional waves of over 20 meters have been reported in association with hurricanes and that there are numerous reports of waves 1015 meters. A NDBO study, (1978), [20], indicates that hurricanes can cause a temperature anomaly of $-3^{\circ} \mathrm{C}$ for a period of four 
days. While this result was measured in the Gulf of Mexico, it should be indicative of the effects of hurricanes on the thermal resource anywhere in the tropics, including the waters off Sri Lanka. 
TABLE V-1: CLIMATIC SUMMARY FOR COLOMBO, SRI LANKA (Elevation 7 meters, Latitude $0654 \mathrm{~N}$, Longitude $7952 \mathrm{E}$ ). From U.S. Naval Weather Service (1973), [ $\underline{36}]$.

\begin{tabular}{|c|c|c|c|c|c|c|c|c|c|c|c|c|}
\hline \multirow[b]{2}{*}{ PARAMETER } & \multicolumn{12}{|c|}{ MONTH } \\
\hline & JAN & FEB & MAR & $A P R$ & MAY & JUN & JUL & AUG & SEP & OCT & NOV & $\mathrm{DEC}$ \\
\hline ABSOLUTE MAX TEMP $\left({ }^{\circ} \mathrm{C}\right)$ & 35 & 36 & 36 & 37 & 33 & 36 & 32 & 31 & 32 & 32 & 32 & 33 \\
\hline AVERAGE MAX TEMP $\left({ }^{\circ} \mathrm{C}\right)$ & 31 & 31 & 29 & 32 & 31 & 31 & 29 & 29 & 29 & 29 & 29 & 29 \\
\hline MEAN TEMP $\left({ }^{\circ} \mathrm{C}\right)$ & 26 & 27 & 26 & 28 & 28 & 27 & 27 & 27 & 27 & 27 & 26 & 26 \\
\hline AVERAGE MIN TEMP $\left({ }^{\circ} \mathrm{C}\right)$ & 22 & 23 & 24 & 25 & 26 & 25 & 25 & 25 & 25 & 24 & 23 & 22 \\
\hline ABSOLUTE MIN TEMF $\left({ }^{\circ} \mathrm{C}\right)$ & 15 & 16 & 18 & 21 & 21 & 22 & 22 & 21 & 22 & 21 & 19 & 17 \\
\hline AVERAGE RAINFALL (MM) & 89 & 69 & 147 & 231 & 371 & 224 & 135 & 109 & 160 & 348 & 315 & 147 \\
\hline MEAN NO. DAYS RAIN & 10 & 6 & 12 & 17 & 23 & 22 & 16 & 14 & 18 & 22 & 20 & 12 \\
\hline MEAN NO.DAYS THUNDERSTORM & 7 & 7 & 13 & 16 & 12 & 4 & 1 & 2 & 3 & 8 & 12 & 8 \\
\hline MEAN NO. DAYS FOG & 3 & 6 & 5 & 1 & $<1$ & 1 & 1 & 1 & 1 & 1 & 4 & 4 \\
\hline MEAN RELATIVE HUMIDITY $(\%)$ & 69 & 69 & 70 & 72 & 75 & 74 & 73 & 73 & 72 & 72 & 71 & 69 \\
\hline PREVAILING WIND DIRECTION & $\mathrm{NE}$ & $\mathrm{NE}$ & $\mathrm{W}$ & $w$ & W & W & W & $\mathrm{W}$ & SW & W & $\mathrm{NE}$ & $\mathrm{NE}$ \\
\hline MEAN WIND SPEED (N/S) & 4 & 3 & 4 & 4 & 5 & 5 & 4.5 & 4.5 & 4 & 4.5 & 3 & 4 \\
\hline
\end{tabular}




$$
\begin{aligned}
& \text { TABLE V-2: WIND FLOW STATISTICS FOR WATER AREAS } \\
& \text { AROUND SRI LANKA (from } \\
& \text { and U.S. Dept. of Agriculture, 1938, [31]). }
\end{aligned}
$$

\begin{tabular}{|c|c|c|c|c|c|c|}
\hline & TAN & MAR & MAY & JUL & SEP & NOV \\
\hline $\begin{array}{l}\text { Resultant wind } \\
\text { direction in tens } \\
\text { of degrees from } \\
\text { North }\end{array}$ & 04 & 05 & 23 & 23 & 23 & 06 \\
\hline $\begin{array}{l}\text { Resultant wind } \\
\text { speed in meters/ } \\
\text { seo }\end{array}$ & 4 & 2 & 4 & 6 & 6 & 2 \\
\hline $\begin{array}{l}\text { Wind steadiness } \\
\text { in percent }\end{array}$ & 75 & 48 & 71 & 86 & 81 & 49 \\
\hline $\begin{array}{l}\text { Winds over Beufort } \\
\text { force } 7(>15 \mathrm{~m} / \mathrm{s}) \\
\text { in percent }\end{array}$ & 0 & 0 & $1-5$ & $1-5$ & $1-5$ & $1-5$ \\
\hline
\end{tabular}

$\mathrm{V}-4$ 




FIGURE V-I: ANNUAL PREFERRED STORM TRACKS FOR TROPICAL STORMS (Crutcher and Quayle, 1974, (7]). 


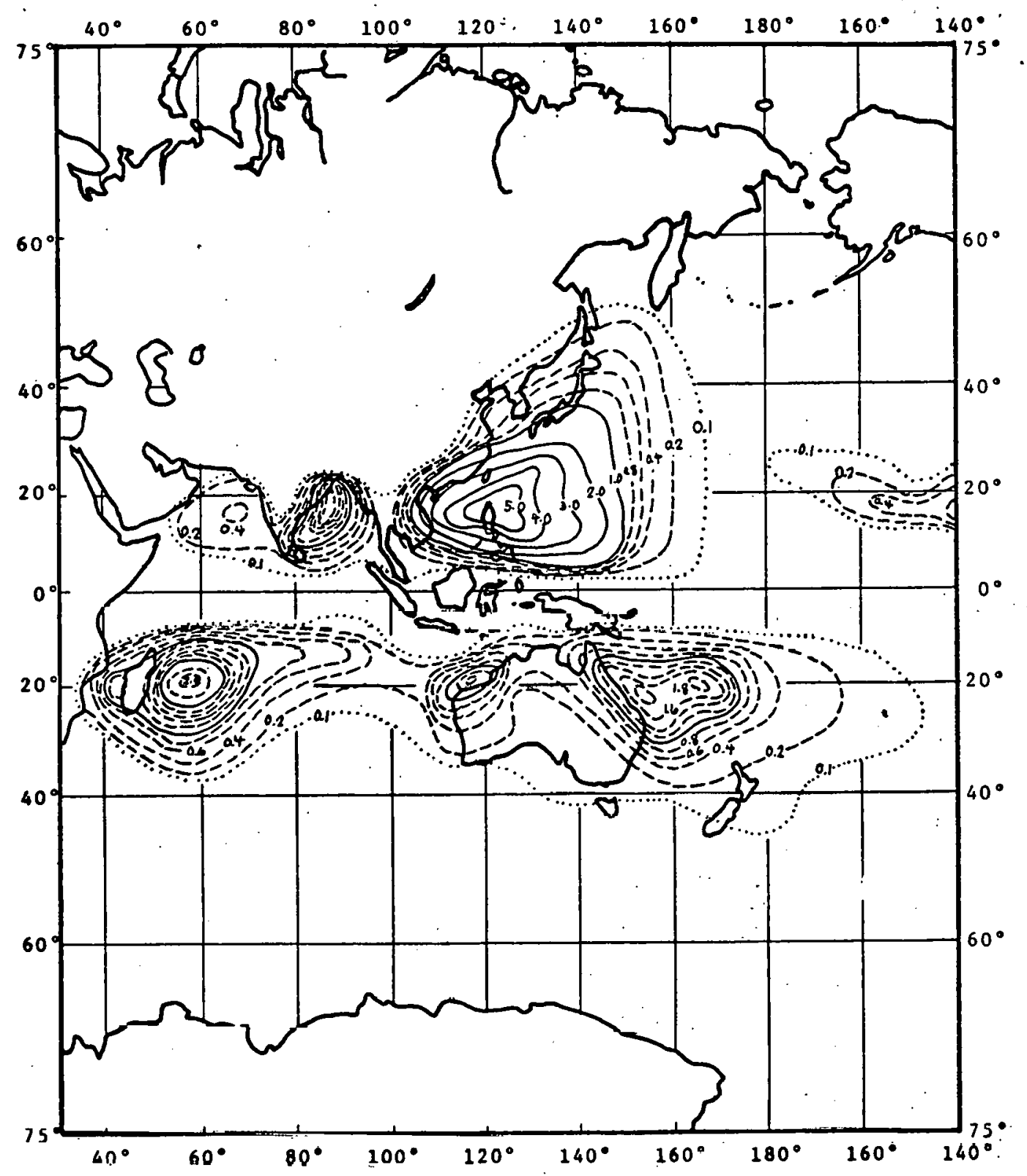

FIGURE V-2: AVERAGE NUMBER OF TROPICAL CYCLONES PER $5^{\circ}$ SQUARE PER YEAR (Crutcher and Quayle; 1974, (7]). 
TABLE V-3: TROPICAL STORM TRACK STATISTICS FOR THE SRI LANKA

AREA. From U.S. Naval Weather Service (1973); [36].

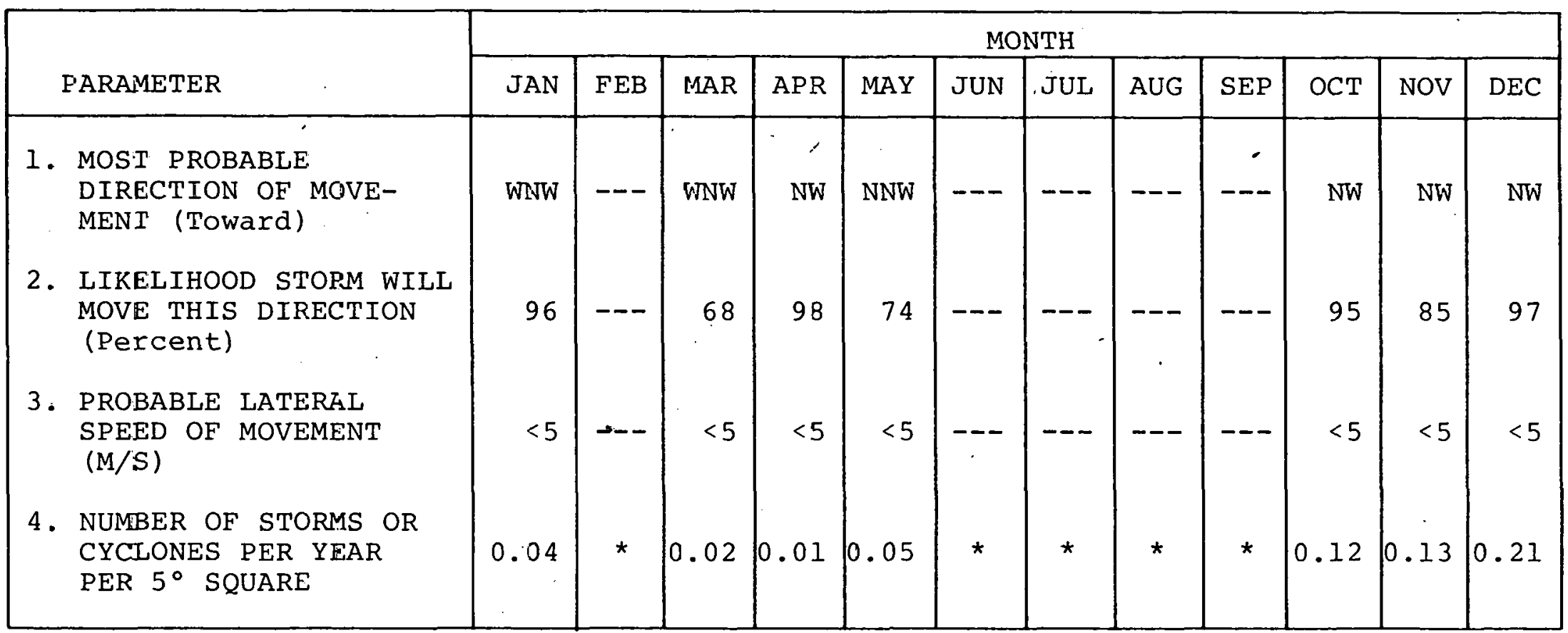

* None Observed In Two $5^{\circ}$ Squares Around Sri Lanka (5-10N, 75-85E). 
VI. SEA AND SWELL CHARACTERISTICS

High sea and swell conditions are a consideration, though not a major concern for OTEC plants off Sri Lanka. The distribution of high sea and swell conditions, however, shows that extreme conditions occur here more often than the other studied sites (Jakarta, Mombassa) in the Indian Ocean geographic region.

The direction of the waves usually follows the direction of the monsoonal wind pattern. The wave amplitudes during the northeast monsoon are lower then during the southwest monsoon season. The average height of the waves are just under 1 meter. During June and July, southwesterly winds blowing steadily over a longer fetch gives rise to a steady state for most of the month and the roughest average sea con'ditions of the year (in spite of the larger number of cyclones late in the year). Table VI-l shows monthly wave characteristics for Sri Lanka reported by Srivastava, Vyayaraza and Joseph (1972), [29].

Table VI-2, taken from Ocean Wave Statistics (1967), [19], presents a statistical breakdown showing the number of observations in various height versus period categories. This summary is based upon actual ships observations from a somewhat larger region around Sri Lanka; however, they are generally representative of that monsoonal flow which characterizes the area, 
TABLE VI-1: SUMMARY OF W.AVE CHARACTERISTICS PROUND SRI LANKA.

From Srivastava, Vyayaraza and Joseph (1972), .29].

\begin{tabular}{|c|c|c|c|c|c|c|c|c|}
\hline \multirow{3}{*}{ - } & \multirow[b]{2}{*}{ MON?H } & \multirow[b]{2}{*}{ PARAMETER } & \multicolumn{5}{|c|}{ IREA } & \multirow[b]{2}{*}{$\begin{array}{c}5-7 N \\
8 I-83 E\end{array}$} \\
\hline & & & $\begin{array}{r}9-11 N \\
79-81 \mathrm{E}\end{array}$ & $\begin{array}{c}7-9 \mathrm{~N} \\
79-81 \mathrm{E}\end{array}$ & $\begin{array}{c}5-7 \mathrm{~N} \\
79-81 \mathrm{E}\end{array}$ & $\begin{array}{r}9-11 N \\
81-33 E\end{array}$ & $\begin{array}{c}7-9 N \\
8 I-83 E\end{array}$ & \\
\hline & JANUARS & $\begin{array}{l}\mathrm{H}_{1 / 3} \\
\mathrm{~S} \\
\mathrm{D}\end{array}$ & $\begin{array}{l}1.0 \\
1.26 \\
\mathrm{NE}\end{array}$ & $\begin{array}{l}1.0 \\
0.86 \\
\text { NNE }\end{array}$ & $\begin{array}{l}1.0 \\
0.62 \\
\mathrm{~N}\end{array}$ & $\begin{array}{l}1.5 \\
0.59 \\
N E\end{array}$ & $\begin{array}{l}1.3 \\
0.64 \\
\mathrm{NE}\end{array}$ & $\begin{array}{c}1.5 \\
0.56 \\
\mathrm{NE}\end{array}$ \\
\hline & MARCH & $\begin{array}{l}\mathrm{H}_{1 / 3} \\
\mathrm{~S} \\
\mathrm{D}\end{array}$ & $\begin{array}{l}0.8 \\
0.53 \\
\mathrm{NE}\end{array}$ & $\begin{array}{l}1.0 \\
0.54 \\
\mathrm{~N}\end{array}$ & $\begin{array}{l}0.7 \\
0.71 \\
\mathrm{~N}\end{array}$ & $\begin{array}{l}0.3 \\
0.84 \\
\mathrm{NE}\end{array}$ & $\begin{array}{l}0.8 \\
0.78 \\
\text { NNE }\end{array}$ & $\begin{array}{l}0.8 \\
0.81 \\
N N E\end{array}$ \\
\hline & JUNE & $\begin{array}{l}\mathrm{H}_{1 / 3} \\
\mathrm{~S} \\
\mathrm{D}\end{array}$ & $\begin{array}{l}1.6 \\
1.02 \\
\text { SW }\end{array}$ & $\begin{array}{l}1.2 \\
0.68 \\
S W\end{array}$ & $\begin{array}{l}1.2 \\
0.69 \\
\text { SW }\end{array}$ & $\begin{array}{l}1.8 \\
1.24 \\
S W_{1}\end{array}$ & $\begin{array}{l}1.3 \\
0.6 .4 \\
\text { SW }\end{array}$ & $\begin{array}{l}2.1 \\
0.84 \\
\text { SW }\end{array}$ \\
\hline & JULY & $\begin{array}{l}\mathrm{H}_{1 / 3} \\
\mathrm{~S} \\
\mathrm{D}\end{array}$ & $\begin{array}{l}1.2 \\
0.72 \\
\text { SSW }\end{array}$ & $\begin{array}{l}1.5 \\
0.50 \\
\text { SSW }\end{array}$ & $\begin{array}{l}1.3 \\
0.68 \\
S W\end{array}$ & $\begin{array}{l}1.3 \\
\text { C. } 72 \\
\text { SW }\end{array}$ & $\begin{array}{l}1.0 \\
0.71 \\
\text { SSW }\end{array}$ & $\begin{array}{c}1.7 \\
0.93 \\
\text { SW }\end{array}$ \\
\hline & AUGUST & $\begin{array}{l}\mathrm{H}_{1 / 3} \\
\mathrm{~S} \\
\mathrm{D}\end{array}$ & $\begin{array}{l}1.2 \\
0.61 \\
\mathrm{~s}\end{array}$ & $\begin{array}{l}1.5 \\
0.39 \\
\text { WSW }\end{array}$ & $\begin{array}{l}1.3 \\
0.68 \\
\text { SW }\end{array}$ & $\begin{array}{l}1.2 \\
0.79 \\
\text { SW }\end{array}$ & $\begin{array}{l}1.1 \\
1.07 \\
s\end{array}$ & $\begin{array}{l}1.5 \\
0.48 \\
\text { SW }\end{array}$ \\
\hline & OCTCBER & $\begin{array}{l}\mathrm{H}_{1 / 3} \\
\mathrm{~S} \\
\mathrm{D}\end{array}$ & $\begin{array}{l}1.0 \\
1.1-3 \\
\text { SSE }\end{array}$ & $\begin{array}{l}1.9 \\
0.85 \\
\text { SSW }\end{array}$ & $\begin{array}{l}1.2 \\
0.83 \\
\text { SW }\end{array}$ & $\begin{array}{c}0.8 \\
0.75 \\
\text { S.W }\end{array}$ & $\begin{array}{l}1.0 \\
1.00 \\
\mathrm{~S}\end{array}$ & $\begin{array}{l}1.1 \\
0.96 \\
\text { SW }\end{array}$ \\
\hline . & NOVEMBER & $\begin{array}{l}\mathrm{H}_{1 / 3} \\
\mathrm{~S} \\
\mathrm{D}\end{array}$ & $\begin{array}{l}1.0 \\
0.94 \\
\mathrm{~N}\end{array}$ & $\begin{array}{l}0.7 \\
0.26 \\
\mathrm{~N}\end{array}$ & $\begin{array}{l}1.0 \\
0.85 \\
\text { NNW }\end{array}$ & $\begin{array}{l}0.8 \\
0.55 \\
\mathbb{8}\end{array}$ & $\begin{array}{l}0.8 \\
0.69 \\
\mathrm{~N}\end{array}$ & $\begin{array}{l}0.5 \\
0.91 \\
\text { NNE }\end{array}$ \\
\hline
\end{tabular}

$\mathrm{H}_{1 / 3}=$ Average "Significant" wave height in meters.

$\mathrm{S}=$ Standard deviation of average height in meters.

$\mathrm{D}=$ Predominant wave direction (direction from which waves are coming).

[NOT: : Predominant wave periods are less than 5 seconds in a-1 cases.] 
TABLE VI-2: STATISTICAL BREAKDOWN SHOWING NUMBER OF SHIPS

OBSERVATIONS AROUND SRI LANKA REPORTING VARIOUS

HEIGHT/PERIOD COMBINATIONS. (AII Seasons)

Wave Statistics (19.67), [19].

\begin{tabular}{|c|c|c|c|c|c|c|c|c|c|c|c|c|c|}
\hline $\begin{array}{l}\text { Wave Height } \\
\text { (meters) }\end{array}$ & $\mathrm{Calm}$ & $<5$ & $6-7$ & $\begin{array}{l}\text { Wav } \\
8-9\end{array}$ & $\begin{array}{l}\text { Perioc } \\
10-11\end{array}$ & $\begin{array}{l}\text { (Secor } \\
12-13 \\
\end{array}$ & $\begin{array}{l}14-15 \\
\end{array}$ & $16-17$ & $18-19$ & $20-21$ & $\begin{array}{l}\text { over } \\
21 \\
\end{array}$ & Total & $\begin{array}{l}\text { Percent of } \\
\text { Grand Total }\end{array}$ \\
\hline 0.25 & 1392 & 1718 & 28 & 11 & 13 & & 2 & 1 & 2 & 33 & 16 & 3216 & 11 \\
\hline 0.5 & 96 & 3607 & 326 & 84 & 17 & 7 & 4 & 1 & 1 & 5 & 134 & 4282 & 15 \\
\hline 1.0 & 70 & 5099 & 2102 & 488 & 131 & 56 & 10 & 3 & 2 & 12 & 53 & 8026 & 28 \\
\hline 1.5 & 70 & 2060 & 3143 & 974 & 245 & 95 & 19 & 11 & 2 & 1 & 1 & 6621 & 23 \\
\hline 2.0 & 43 & 444 & 1660 & 1014 & 200 & 73 & 15 & 4 & & & 1 & 3454 & 12 \\
\hline 2.5 & 11 & 146 & 608 & 558 & 192 & 66 & 19 & 2 & & 1 & 2 & 1605 & 6 \\
\hline 3.0 & 9 & $4 L$ & 156 & 246 & 101 & 39 & 9 & 2 & & & & 606 & 2 \\
\hline 3.5 & 7 & 13 & 64 & 94 & 45 & 17 & 7 & & & & & 247 & 1 \\
\hline 4.C & 1 & 11 & 16 & 27 & 30 & 14 & 2 & & & & & 102 & $<1$ \\
\hline 4.5 & 1 & 3 & 5 & 7 & 13 & 12 & & & & & & 41 & $<1$ \\
\hline 5.0 & & 1 & 1 & . & 1 & 4 & & & & & & 7 & $<1$ \\
\hline 5.5 & & 1 & & 4 & & 1 & & & & & & 6 & . $<1$ \\
\hline 6.0 & & & & 2 & & & & & & & & 3 & $<1$ \\
\hline 6.5 & & & & 1 & & & & & & & & 1 & $<1$ \\
\hline Total & 1700 & $1314 i$ & 8109 & 3510 & 988 & 384 & 87 & 25 & 7 & 53 & 207 & 28217 & \\
\hline $\begin{array}{l}\text { Percent } \\
\text { of Granć } \\
\text { Total }\end{array}$ & 6 & 47 & 29 & 12 & 4 & 1 & $<1$ & $<1$ & $<1$ & $<1$ & 1 & & \\
\hline
\end{tabular}


"VII.'CURRENTS

The surface current structure in this area responds to changes in the monsoons, and is largely determined by prevailing winds. The beginning of the northeast monsoons in November causes a shift in circulation to a westward and northwestward pattern, flowing from Sri Lanka up around India and along the western Indian coast. During the summer months, the southwest monsoon controls the pattern and the circulation is generally eastward and southeastward through September. During the monsoons, the currents are generally moderate in strength with little variation in direction. Düing (1970, [14]) found that the effects on current structure due to monsoonal winds usually penetrate to a depth of about 400 meters in the Indian Ocean but may penetrate to only 250 meters around Sri Lanka. He further concluded, the insufficient current data is available from this area to define current structure with depth on a monthly basis. The Encyclopedia of Oceanography (1966), [30] states that surface currents to the south of Sri Lanka average about $50-100 \mathrm{~cm} / \mathrm{sec}$ and may sometimes be as great as $150 \mathrm{~cm} / \mathrm{sec}$. Some values of surface current speeds reported by the National Oceanographic Data Center [23] for the Sri Lanka area are shown in Table VII-1. 
TABLE VII-1: TYPICAL SURFACE CURRENT SPEEDS AROUND SRI LANKA IN CM/SEC.

From National Oceanographic Data Center [31].

\begin{tabular}{|c|c|c|c|c|}
\hline \multirow{2}{*}{ AREA } & \multicolumn{4}{|c|}{ MONTH } \\
\cline { 2 - 5 } & OCT & NOV & DEC & JAN \\
\hline WEST CONET & $5-15$ & $15-\not 1$ & $26-51$ & $36-77$ \\
SOUTH COAST & $15-31$ & $26-77$ & $51-102$ & $36-77$ \\
\hline
\end{tabular}


1. Adamec, D., and O'Brien, J.J., November 1978, "The Seasonal Upwelling in the Gulf of Guinea Due to Remote Forcing",. J. Phys. Oceanogr., 8, No. 6, 1050-1060.

2. Atwood, D.K., et al., 1976, Ocean Thermal Energy Conversion, Resource Assessment and Environment Impact for Proposed Puerto Rico Site, University. of Puerto Rico.

3. Avery, W.H., et al., 1976, Maritime and Construction Aspects of Ocean Thermal Energy Conversion (OTEC) Plant Ships, The John Hopkins University Applied Physics Laboratory, Laurel, Maryland.

4. Bathen, K.H., et al., 1977, "Consolidated Oceanographic and Meteorological Data for Four North Pacific OTEC Sites", University of Hawaii.

5. Bigelow, H.B., and W.T. Emundson, 1947, Wind Waves at Sea, U.S. Hydrographic office, Washington, D.C.

6. Colburn, J.G., 1974, "The Thermal Structure of the Indian "Ocean", International Indian Ocean Expedition Oceanographic Monograph No., 2; The. University Press of Hawaii; Honolulu, Hawaii.

7. Crutcher, H.L. and R.G. Quayle, 1974, "Mariners Worldwide Climatic Guide to Tropical Storms at Sea", NAVAIR 501C-6I, Naval Weather Service; Asheville, N.C.

8. Defense Mapping Agency Hydrographic/Topographic Center, 1978, Pilot Chart of the North Pacific, DMA Stock Numbers PIIOT 557801, 557804, 557810, Washington, D.C.

9. Defense Mapping Agency Hydrographic/Topographic Center, 1978, Pilot Chart of the North Atlantic Ocean, DMA. Stock Numbers PILOT 167801, 167804, 167807, 167810, Washington, D.C.

10. Defense Mapping Agency Hydrographic Center, South Pacific Ocean, Sheet IV, Pub. N.O. 623, revised 1974, Washington, D.C.

11. Defense Mapping Agency Hydrographic Center, Indian Ocean, Northern Part, Pub 1No. 721, 1974, Washington, D.C. .

12. Defense Mapping Agency Hydrographic Center, Gulf of Mexico and Carribean Sea, Pub. No. 410, revised 1973, Washington, D.C. 
13. Defense Mapping Agency Hydrographic Center, North Atlantic Ocean, Southeastern Sheet, Publication N.O. 125, 4th ed., 1974, Washington, D.C.

14. Düing, W., 1970; "The Monsoon Regime of the Currents in the Indian Ocean", International Indian Ocean Expedition Oceanographic Monograph No. 1, Hawaii Institute of Geophysics Contribution No. 331, the University of Hawaii Press; Honolulu, Hawaii.

15. Düing, W. and F. Schott; March 1978, "Measurements in the Source Region of the Somali Current during the Monsoon Reversal", J. Phys. Oceanogr., 8, 278-289.

16. Emilsson, J., 1970, "On the Upper Layer Circulation in the Cayman Sea", from the symposium on the Investigations and Resources of the Caribbean Sea and Adjacent Regions, UNESCO, Paris France.

17. Fleet Numerical Weather Central (FNWC), FNWC and National. Oceanographic Data Center digitized reports.

18. Gentry, R.C., 1970, "Hurricanes, One of the Major Features of Air-Sea Interaction in the Caribbean Sea", from the Symposium on the Investigation and Resources of the Caribbean Sea and Adjacent Regions, UNESCO, Paris, France.

19. Hogben, N., and F. Lumb, 1967, Ocean Wave Statistics; National Physical Laboratory, Ministry of Technology, London. Her Majesty's stationery office.

20. Johnson, A. and S. Denwick, 1978; "Data Report Buoy Observations During Hurricanes Anita and Babe, AugustSeptember, 1977", NOAA Data Buoy Office, National. Space Technology Laboratories, NSTL Station; Mississippi.

21. Leipper, D.F., 1967, "Observed Ocean Conditions and Furricane Hilda, 1964. J. Atmos Sci., 24, p 182-196.

22. MCFadden J.D., "Airborne Investigations of the Effects of Hurricanes on the Thermal Structure of the surface Layer of the Ocean", from the Symposium on Investigation and Resources of the Caribbean Sea and Adjacent Regions, UNESCO, Paris France.

23. National Oceanographic Data Center, The Variability of Water Masses in the Indian Ocean, Publication G-11, Washington, D.C. 
24. National Oceanographic Data Center, Data File BTG75A, Washington, D.C., 1977.

25. National Oceanographic Data Center, Data Files SD40A5/0A6 from SD76A (1/30/76) 3509 STA: Washington, D.C., 1977.

26. National Science Foundation, 1972, Meteorological Atlas of the International Indian Ocean Expedition, Volume 7, Washington, D.C.

27. O'Brien, J.J., and R.O. Reid, 1967, "The Non-Linear Response of a Two Layer Baroclinic Ocean to a Stationery Axially Symetric Hurricane", J. Atmos. Sci., 24, p 197215 .

28. Ramage, C.D., 1972, "Indian Ocean Surface Meteorology", International Indian Ocean Expedition, Collective Reprints VIII, Contribution No. 624, pgs 407-540; Paris, France.

29. Sirvastava, P.S., P.K. Vyayarayou and M.X. Joseph, 1972 "Monthly Wave Characteristics of the Bay of Bengal", International Indian Ocean Expedition, Collective Reprints VIII, Contribution No. 625, Paris, France.

30. The Enclyopedia of Oceanography, 1966, Reinhold Publishing Corp., New York, New York:

31. U.S. Department of Agriculture, Weather Bureau, 1938, "Atlas of Climatic Charts of the Oceans", Washington, D.C.

32. U.S. Department of Commerce, NOAA, 1971, Eastropac Atlas, Volume 3, Washington, D.C.

33. U.S. Navy, 1975, Marine Climatic Atlas of the World, Volume III, Indian Ocean, Washington, D.C.

34. U.S. Navy Hydrographic Office, 1964, Atlas of Sea and Swell Charts, Northeastern Pacific Ocean, Publication No. 799D, revised 1976, Washington, D.C.

35. U.S. Naval Weather Service, September 1974, Climatic Summaries For Major Indian Ocean Ports and Waters, NAVAIR 50-1C-63, Asheville, N.C.

36. U.S. Naval Weather Service, November 1973, Climatic Summaries For Major Seventh Fleet Ports and Waters, NAVAIR 50-1C-62, Asheville, N.C.

37. U.S. Naval Oceanographic Office, 1963, Oceanographic Atlas of the North Atlantic Ocean, Washington, D.C.

if $\mathrm{R}-3$ 
38. U.S. Naval Oceanographic Office, Bathymetric Atlas of the Northeastern Pacific Ocean, Pub No. 1303-s, No. $0902 \mathrm{~N}, 0903 \mathrm{~N}, 1002 \mathrm{~N}, 1003 \mathrm{~N}$, Washington, D.C.

39. U.S. Naval Oceanographic Office, Indian Ocean, AfricaEast Coast Publication No. 724, 1st ed., 1974, Washington, D.C.

40. U.S. Naval Oceanographic Office, 1971, Eathymetric Atlas of the Northeastern Pacific Ocean, H.O. Pub No. $1303-\mathrm{S}, \mathrm{N} .0 .1104 \mathrm{~N}, 1105 \mathrm{~N}, 1204 \mathrm{~N}, 1204 \mathrm{~N}$, Washington, D.C.

41. U.S. Naval Oceanographic Office, 1971, Bathymetric Atlas of the Northeastern Pacific Ocean, H.O. Pub N.O. $1301-S, 2403 \mathrm{~N}, 2040 \mathrm{~N}$, Washington, D.C.

42. U.S. Naval Oceanographic Office, 1970, Bathymetric $\lambda$ tlas of the Northwestern Parific Ocean, H.O, Pub. 1201-S, N.0. 2203N, washington, D.C.

43. Wolff, P.M. and W.E. Hubert, 1976, "Ocean Thermal Energy Conversion: Resource, Ecological and Environmental Studies", Contract No. NSF-C1020, Ocean Data Systems, Inc., Monterey, California.

44. Wolff, P.M., et al, 1977, "OTEC Resource Report for Hawaii", Contract EG-77-C-01-4028, Ocean Data Systems, Inc., Monterey, California.

45. Wyrtki, K., 1972, "The Upwelling in the Region Between Java and Australia during the South-East Monsoon, Collected reprints of the International Indian Ocean Expedition, Volume I, Contribution No. 15, pp 151-161.

46. Wyrtki, K., 1972, "Geopotential Topographics and Associated Circulation in the South Eastern Indian Ocean", Collected reprints of the International Indian Ocean Expedition, Volume I, contribution No. 14 .

47. Wyrtki, K., 1971, Oceanographic Atlas of the International Ocean Expedition, National Science Foundation, NSF-IOE1, Washington, D.C. 